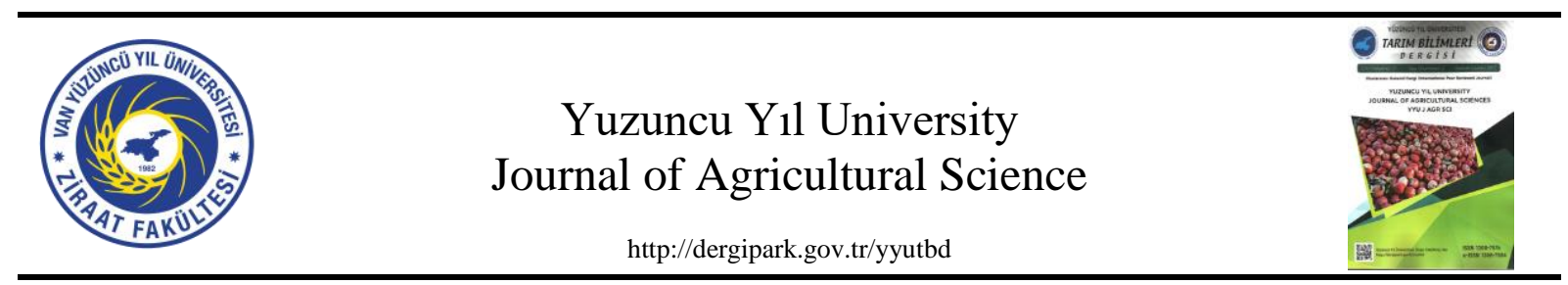

Araştırma Makalesi (Research Article)

\title{
Antimicrobial and Antioxidant effect of Ficaria verna Huds.
}

\section{Şule İNCI**1, Ayşe EREN², Sevda KIRBAĞ ${ }^{3}$, Ahmet İsmail ÖZKAN ${ }^{4}$}

${ }^{1,3}$ Firat Üniversity, Science Faculty, Department of Biology, 23270, Elazı ̆, Turkey

${ }^{2,4}$ Dicle Üniversity, Science Faculty, Department of Molecular Biology and Genetics, Diyarbakır, Turkey

${ }^{1}$ https://orcid.org/0000-0002-4022-5269 ${ }^{2}$ https://orcid.org/0000-0002-5601-6808 ${ }^{3}$ https://orcid.org/0000-0002-4337-8236 ${ }^{4}$ https://orcid.org/0000-0002-4511-2386

*Sorumlu yazar e-posta: sule.inci@hotmail.com

\section{Article Info}

Received: 09.11.2020

Accepted: 23.05.2021

Online Published 30.06.2021

DOI: $10.29133 /$ yyutbd.823401

\section{Keywords}

Antimicrobial effect,

Antioxidant effect,

Ranunculus ficaria,

Medical plant.

\begin{abstract}
Ficaria verna Huds. is a plant belonging to the Ranunculaceae family, known as mole grass and celandine among the people. It is known to have antiinflammatory and anti-haemorrhagic pharmaceutical effects. In this study, it was aimed to determine the antimicrobial effect of different concentrations of $F$. verna extracts obtained from methanol, ethanol and chloroform and the antioxidant activity of different concentrations of the extract obtained from methanol. In the results obtained, the best antimicrobial effect (17-20 mm) against Staphylococcus aureus, Escherichia coli, Klebsiella pneumoniae, Bacillus megaterium, Salmonella thypii and Candida albicans was determined in the methanol extract of $F$. verna at a concentration of $1000 \mu \mathrm{g}$. It was observed that the scavenging effect of the DPPH radical of $F$. verna increased depending on increasing concentrations.
\end{abstract}

\section{Ficaria verna Huds.'nin Antimikrobiyal ve Antioksidan Etkisi}

\section{Makale Bilgileri}

Geliș: 09.11.2020

Kabul: 23.05.2021

Online Yayınlanma 30.06.2021

DOI: $10.29133 /$ yyutbd.823401

\section{Anahtar kelimeler}

Antimikrobiyal etki, Antioksidan etki, Ranunculus ficaria, T1bbi bitki.

\begin{abstract}
Öz: Ficaria verna Huds. halk arasında köstebek otu ve kırlangıç otu adıyla bilinen ve Ranunculaceae familyasına ait bir bitkidir. Antienflamatuar ve antihemorajik gibi farmasötik etkilerinin olduğu bilinmektedir. Halk arasında hemoroide karşı kullanılmaktadır. Bu çalışmada $F$. verna'nın metanol, etanol ve kloroformdan elde edilen ekstraklarının farklı konsantrasyonlarının antimikrobiyal etkisi ile metanoldan elde edilen ekstresinin farkl1 konsantrasyonlarının antioksidan aktivitesinin belirlenmesi amaçlanmıştır. Elde edilen sonuçlarda $F$. verna'nın metanol ekstresi $1000 \mu \mathrm{g}$ konsantrasonda Staphylococcus aureus, Escherichia coli, Klebsiella pneumoniae, Bacillus megaterium, Salmonella thypii ve Candida albicans'a karşı en iyi antimikrobiyal etki $(17-20 \mathrm{~mm})$ göstermiştir. $F$. verna'nın DPPH radikalinin süpürücü etkisinin artan konsantrasyonlara bağlı arttı̆̆ gözlemlenmiştir.
\end{abstract}

\section{Introduction}

Plants are used in different ways depending on the disease since ancient times and are considered as natural medicines (Durdevic et al., 2013). Mankind was discovered this healing effect of plants long ago and continues to use it today (Altay et al., 2015; Ozaslan and Oguzkan, 2018). Especially, with the increasing number of diseases, side effects of drugs and the lack of adequate response in treatment, the use of natural medicines of herbal origin is increasing (Doğan and Avc1, 2018). Herbal preparations are 
known to have pharmacological effects such as anticancer, antimicrobial, antioxidant, anti-diarrhea, analgesic and wound healing (Karahan and Ilçim 2008; Karahan et al., 2016; Ozaslan and Oguzkan, 2018; Karahan et al., 2019; ). For this reason, it is very important to examine herbal preparations and to investigate their medical effects.

Various species belonging to the Ranunculaceae family are used as spices and herbal medicine (Malik et al., 2017). These species are known to be used in conditions such as cancer, cardiac dysfunctions, various inflammation and severe hemostasis (Darshan and Doreswamy, 2004; Salem, 2005; Dewick, 2009). In addition, some species of this genus are known to have biological activities such as antibacterial, antiviral and antiprotozoal (Kaya et al., 2010). Ficaria verna Huds., which belongs to the Ranunculaceae family, is used in folk medicine for anti-inflammatory and anti-haemorrhagic effects. Especially, tuberous and dry root parts of the plant are used in treatment (Neag et al., 2017).

In this study, it was aimed to determine the antimicrobial effect of different concentrations of of the flower and leaf parts of $F$. verna extracts obtained from methanol, ethanol and chloroform and the antioxidant activity of different concentrations of the extract obtained from methanol.

\section{Materials and Methods}

\subsection{Obtaining and preparation of plant material}

F. verna (syn. Ranunculus ficaria L.) was purchased commercially from a local herbalist in 2020. The taxonomic identification of plant material was determined by using the Flora of Turkey (Davis, 1965; The Plant List, 2021); it was performed by Prof Dr. Şemsettin Civelek who is a systematicbotanic specialist from Firat University. The plant material was pulverized. 0.5 grams of sample was taken. Each sample was kept in an orbital shaker at $100 \mathrm{rpm}$ for 72 hours to obtain an extract using 100 $\mathrm{ml}$ 96\% methanol, ethanol and chloroform solvents. It was then filtered using Whatman filter paper.

\subsection{Determination of antimicrobial effect}

\subsubsection{Test microorganisms}

In this study; Staphylococcus aureus ATCC25923, Escherichia coli ATCC25322, Klebsiella pneumoniae ATCC 700603, Bacillus megaterium DSM32, Salmonella thypii ve Candida albicans FMC17 microorganisms were used. Microorganism cultures were obtained from Firat University, Faculty of Science, Department of Biology, Microbiology Laboratory culture collection.

\subsubsection{Preparation of microorganism cultures and testing for antimicrobial effect}

The antimicrobial activity of extracts of $F$. verna obtained from ethanol, chloroform and methanol solvents were determined according to the disk diffusion method (Erecevit Sönmez et al., 2019). Bacteria strains (Staphylococcus aureus ATCC25923, Escherichia coli ATCC25322, Klebsiella pneumoniae ATCC 700603, Bacillus megaterium DSM32, Salmonella thypii) were inoculated into Nutrient Broth (Difco) for 24 hours at $35 \pm 1{ }^{\circ} \mathrm{C}$ and yeast strains (Candida albicans FMC17) were incubated in Malt Extract Broth (Difco) for 48 hours at $25 \pm 1{ }^{\circ} \mathrm{C}$. The culture of the prepared bacteria and yeast broth, respectively; was inoculated into Müeller Hinton Agar and Sabouraud Dextrose Agar at a rate of $1 \%\left(10^{6}\right.$ bacteria $\mathrm{ml}^{-1}, 10^{4}$ yeast $\left.\mathrm{ml}^{-1}\right)$. Then, after shaking well, $25 \mathrm{ml}$ was placed in sterile petri dishes of $9 \mathrm{~cm}$ diameter. A homogeneous distribution of the medium was achieved. $6 \mathrm{~mm}$ diameter antimicrobial discs (Oxoid), each impregnated with different extracts of $100 \mu \mathrm{l}(500 \mu \mathrm{g})$ and $200 \mu \mathrm{l}$ $(1000 \mu \mathrm{g})$, were lightly placed on the solidified agar medium. After the petri dishes prepared in this way were kept at $4^{\circ} \mathrm{C}$ for $1.5-2$ hours, the plates inoculated with bacteria were incubated at $37 \pm 0.1^{\circ} \mathrm{C}$ for 24 hours, and the plates inoculated with yeast at $25 \pm 0.1{ }^{\circ} \mathrm{C}$ for 72 hours. As controls, different standard discs were used for bacteria (Streptomycin sulphate $10 \mu \mathrm{g} \mathrm{disc}^{-1}$ ) and yeasts (Nystatin $30 \mu \mathrm{g} \mathrm{disc} \mathrm{d}^{-1}$ ). Dimethyl sulfoxide (DMSO) was used for negative control. Zones of inhibition were measured in $\mathrm{mm}$. 


\subsection{Determination of antioxidant effect}

Antioxidant activity was determined by the free radical scavenging activity of 2,2-diphenyl-1picrylhydrazyl (DPPH) (Sharma and Bhat, 2009; Dimitrova et al., 2010). DPPH solution was prepared to be $0.004 \%$ in methanol. Serial concentrations $\left(1.25,2.5,5,10 \mathrm{mg} \mathrm{ml}^{-1}\right)$ of plant extracts were prepared by dissolving in methanol. $30 \mu 1$ of plant extract was added on $3 \mathrm{ml}$ of DPPH solution. It was left in the dark for 30 minutes at room temperature. Then, reading was done at $517 \mathrm{~nm}$ in the spectrophotometer. The antioxidant activity was repeated three times. Butylated hydroxyanisole (BHA) and methanol were used as controls. The antioxidant activity was calculated by the formula below. AbsControl = Absorbance of DPPH-methanol solution, AbsSample $=$ Absorbance of plant extract.

$\%$ DPPH inhibition $=[($ AbsControl - AbsSample $) /$ AbsControl $] \times 100$

\subsection{Statistical analysis}

The statistical analysis of the study was made according to the kruskal wallis test.

\section{Results}

\subsection{Antimicrobial effect}

Antimicrobial activity results of $F$. verna extracts obtained from methanol, ethanol and chloroform against Staphylococcus aureus, Escherichia coli, Klebsiella pneumoniae, Bacillus megaterium, Salmonella thypii and Candida albicans at different concentrations are given in Table 1.

It was determined that the chloroform extract of $F$. verna at $500 \mu \mathrm{g}$ and $1000 \mu \mathrm{g}$ concentrations did not show antimicrobial effect against all the microorganisms used. (Table 1).

While ethanol extract of $F$. verna at $1000 \mu \mathrm{g}$ concentration was formed the zone $16 \mathrm{~mm}$ against E. coli, $11 \mathrm{~mm}$ against $K$. pneumoniae, $14 \mathrm{~mm}$ against $S$. aureus, $10 \mathrm{~mm}$ against $S$. thypii and $14 \mathrm{~mm}$ against $C$. albicans, it was determined that it did not show an antimicrobial effect at a concentration of $500 \mu \mathrm{g}$ (Table 1).

It was observed that the methanol extract of $F$. verna at $1000 \mu \mathrm{g}$ concentration formed an inhibition zone (17-21 mm) in different ratios against E. coli, K. pneumoniae, S. aureus, S. thypii and $C$. albicans however it was determined that it did not show an antimicrobial effect in methanol extract at $500 \mu \mathrm{g}$ concentration (Table 1).

Table 1. Antimicrobial activity of different concentrations of $F$. verna (mm)

\begin{tabular}{llllll}
\hline & E. coli & K. pneumoniae & S. aureus & S. thypii & C. albicans \\
\hline R.F-C $(500 \mu \mathrm{g})$ & - & - & - & - & - \\
R.F-C $(1000 \mu \mathrm{g})$ & - & - & - & - & - \\
R.F-E $(500 \mu \mathrm{g})$ & - & - & - & - & - \\
R.F-E $(1000 \mu \mathrm{g})$ & 16 & 11 & 14 & 10 & 14 \\
R.F-M $(500 \mu \mathrm{g})$ & - & - & - & - & - \\
R.F-M & 20 & 17 & 21 & 18 & 18 \\
$(1000 \mu \mathrm{g})$ & 12 & 10 & 10 & 30 & 12 \\
Control & & & & & \\
\hline
\end{tabular}

R.F-C: Chloroform extract of $F$. verna; R.F-E: Ethanol extract of $F$. verna; R.F-M: Methanol extract of $F$. verna.

\subsection{Antioxidant effect}

The percentage of inhibition of DPPH radical in different concentrations of the methanol extract of $F$. verna is shown in Table 2.

According to the results, it was determined that the DPPH radical scavenging effect of the methanol extract of $F$. verna increased depend on increasing concentrations (Table 2). 
Table 2. Percent inhibition of the DPPH radical of $F$. verna

\begin{tabular}{ll}
\hline BHA & 91.70 \\
MetOH & 1.56 \\
$1.25 \mathrm{mg} \mathrm{ml}^{-1}$ & 20.90 \\
$2.5 \mathrm{mg} \mathrm{ml}^{-1}$ & 42.38 \\
$5 \mathrm{mg} \mathrm{ml}^{-1}$ & 81.79 \\
$10 \mathrm{mg} \mathrm{ml}^{-1}$ & 95.98 \\
\hline
\end{tabular}

BHT: Butylated hydroxyanisole; MetOH: Methanol.

Values are means \pm S.D.n:3, $\mathrm{p}<0.05$ importantly dissimilar with Kruskal Wallis's test.

\section{Discussion and Conclusion}

In previous studies, the antimicrobial and antioxidant effects of different species of plant extracts belonging to the Ranunculaceae family were determined. Antimicrobial activities of hexane, ethyl acetate, methanol and aqueous extract of $R$. sprunerianus and $R$. marginatus var. trachycarpus against some microorganisms were tested. In the results obtained, it was determined that the antimicrobial effects of these species against $S$. faecalis, $S$. aureus, $S$. epidermidis, B. subtilis, $S$. typhimurium, $P$. aeruginosa, E. aerogenes and E. coli ranged between 128 and $256 \mu \mathrm{g} \mathrm{mL}{ }^{-1}$. (Kaya et al., 2010). It was reported in studies that the inhibition zones of Ranunculus arvensis obtained by using different solvents against E. coli, E. aerogenes, B. bronchiseptica, K. pneumoniae, M. luteus and S. anginosus are $7 \mathrm{~mm}$. It was determined that the same species did not have a significant antifungal effect against A. niger, $A$. flavus, A. fumigates, F. solani and Mucor species (Bhatti et al., 2015). When the results of this study were compared with species such as $R$. sprunerianus, $R$. marginatus var. trachycarpus and Ranunculus arvensis in the literature, it was determined that the antimictobial effect of $F$. verna is different depending on the solvents and the microorganisms used. It was observed that the methanol extract of $F$. verna has a better antimicrobial effect than chloroform and ethanol extracts.

Antioxidant activities of A. hupehensis, A. spicata, C. europaea, H. foetidus, A. vulparia, $T$. altissimus and C. racemosa were determined as 0.325, 0.251, 0.195, 0.172, 0.109, 0.103 and $0.156 \mathrm{TE}$ $\mathrm{g}^{-1}$, respectively. Studies were reported that $R$. ficaria has $80.9 \%$ scavenging effect of DPPH radical at a concentration of $1 \mathrm{mg} \mathrm{ml}^{-1}$ (Barla et al., 2014). In studies, the scavenging effect of the DPPH radical of different concentrations $\left(50-500 \mu \mathrm{g} \mathrm{ml}^{-1}\right)$ of the roots of Ranunculus sceleratus was found to be between $57.50 \% \pm 2.88$ and $21.89 \% \pm 0.75$ (Serag et al., 2020). The scavenging effect of the DPPH radical of hexane, ethyl acetate, methanol and aqueous extracts of $R$. marginatus var. trachycarpus were found to be $10.50 \% \pm 0.30,22.34 \% \pm 0.33,76.58 \% \pm 0.98$ and $45.50 \% \pm 0.50$, respectively. DPPH radical scavenging effect of $R$. sprunerianus hexane, ethyl acetate, methanol and aqueous extracts was found to be $27.60 \% \pm 0.06,37.20 \% \pm 0.09,85.34 \% \pm 0.33$ and $61.09 \% \pm 0.29$, respectively (Kaya et al., 2010). The IC50 value of the DPPH radical scavenging effect of $R$. ficaria extract obtained from glycerol-ethanol and hydroalcoholic solvents was calculated as 1.9 and $243.4 \mu \mathrm{l}$, respectively (Neag et al., 2017). When the results of this study are compared with A. hupehensis, A. spicata, C. europaea, $H$. foetidus, A. vulparia, T. altissimus, $C$. racemosa, $R$. sceleratus, $R$. marginatus var. trachycarpus and $R$. sprunerianus, It was determined that the antioxidant effect of $F$. verna is higher.

In this study, the antimicrobial and antioxidant effects of F.verna were investigated. In the results obtained, it was found that antimicrobial and antioxidant effects increased depending on the increase in concentration. As a result, we think that F.verna can be used as an antioxidant and antimicrobial agent in pharmacological studies.

\section{References}

Altay, V., Karahan, F., Sarcan, Y. B., \& İlçim, A. (2015). An ethnobotanical research on wild plants sold in Kırıkhan district Hatay/Turkey herbalists and local markets. Biyolojik Çeşitlilik ve Koruma, 8(2), 81-91.

Bârlă, G. F., Poroch - Serıţan, M., Sănduleac (Tudosı), E., \& C1orne1 (Ştefăro1), S. E. (2014). Ant1oxıdant activity and total phenolic content in Allium ursinum and Ranunculus ficaria, Journal of Faculty Of Food Engineering, XIII(4), 349 - 353. 
Bhatti, M. Z., Ali, A., Saeed, A., Saeed, A., \& Malik, S. A. (2015). Antimicrobial, antitumor and brine shrimp lethality assay of Ranunculus arvensis L. Extracts. Pakistan Journal of Pharmaceutical Science, 28(3), 945-949.

Darshan, S., Doreswamy, R., (2004). Patented antiinflammatory plant drug development from traditional medicine. Phytotherapy Research, 18, 343-357.

Davis, P.H. (1965). Flora of Turkey and The East Aegean Islands. Edinburgh University Press, Vol. 1., Edinburgh.

Dewick, P.M., (2009). Medicinal Natural Products: a Biosynthetic Approach. Wiley \& Sons, Chichester, UK.

Dimitrova, D. Z, Nedialkov P., \& Kitanov, G. (2010). Radical scavenging and antioxidant activities of methanolic extracts from Hypericum species growing in Bulgaria. Pharmacognosy Magazine. 6, 74-78. Doğan, Ö., Avc1, A. (2018). Bitkilerle tedavi ve ilaç etkileşimleri. Turkiye Klinik Journal Public Health, 4(1), 49-54.

Đurđević, L., Gajić, G., Jarić, S., Kostić, O., Mitrović, M., \& Pavlović, P. (2013). Analysis of benzoic and cinnamic acid derivatives of some medicinal plants in Serbia. Archives of Biological Sciences, 65(2), 603-609.

Erecevit Sönmez, P., Kırbağ, S., \& İnci, Ş. (2019). antifungal and antibacterial effect of Dodder (Cuscuta campestris) used for hepatitis treatment of mothers and newborn infants in province Mardin in Turkey. Yüzüncü Yıl Üniversitesi Tarım Bilimleri Dergisi, 29(4), 722-730.

Karahan, F., Avsar, C., Ozyigit, I. I., \& Berber, I. (2016). Antimicrobial and antioxidant activities of medicinal plant Glycyrrhiza glabra var. glandulifera from different habitats. Biotechnology \& Biotechnological Equipment, 30(4), 797-804.

Karahan, F., İlçım, A. (2017). Radioterapi gören kanser hastalarinda tibbi ve aromatik bitkilerin potansiyel faydaları. Biyolojik Çeşittilik ve Koruma, 10(2), 51-61.

Karahan, F., Ozyigit, I. I., Saracoglu, I. A., Yalcin, I. E., Hocaoğlu Özyiğit, A., \& Ilcim, A. (2020). Heavy metal levels and mineral nutrient status in different parts of various medicinal plants collected from Eastern Mediterranean Region of Turkey. Biologicial Trace Element Research, 197, 316-329.

Kaya, G. İ., Somer, N. Ü., Konyalığlu, S., Yalçın, H. T., Karabay Yavaşoğlu, N. Ü., Sarıkaya, B., \& Önür, M. A. (2010). Antioxidant and antibacterial activities of Ranunculus marginatus var. trachycarpus and $R$. sprunerianus. Turkish Jorurnal of Biology, 34, 139-146.

Malik, J., Tauchen, J., Landa, P., Kutil , Z., Marsik, P., Kloucek, P., Havlik, J., \& Kokosk, L. (2017). In vitro antiinflammatory and antioxidant potential of root extracts from Ranunculaceae species. South African Journal of Botany, 109, 128-137.

Neag, T., Toma, C. C., Olah, N., \& Ardelean, A. (2017). Polyphenols profile and antioxidant activity of some Romanian Ranunculus species. Studia Ubb Chemıa, LXII(3), 75-88.

Ozaslan, M., \& Oguzkan, S. B. (2018). Use of plant extracts in alternative medicine. Pakistan Journal of Biological Science, 21(1), 1-7.

Serag, M. S., Khedr, A. E. H. A., El-Amier, Y. A., \& El-Afify, S. M. (2020). Bioactive constituents and allelopathic activities of the invasive weed Ranunculus sceleratus L. Nile Delta, Egypt. Journal of Experimental Sciences, 11, 1-4.

Sharma O. P., \& Bhat T. K. (2009). DPPH antioxidant assay revisited. Food Chemistry. 113, 12021205.

The Plant List (2021). Publish on the internet; http://www.theplantlist.org/tpl1.1/record/kew-2523483 (accessed April 2021). 